\title{
Alkali-activated binders: A review. Part 2. About materials and binders manufacture
}

\author{
Fernando Pacheco-Torgal ${ }^{\mathrm{a}, *}$, João Castro-Gomes ${ }^{\mathrm{b}, 1}$, Said Jalali ${ }^{\mathrm{c}, 2}$ \\ ${ }^{a}$ Castelo Branco Polytechnic Institute, Department of Civil Engineering, 6000 Castelo Branco, Portugal \\ ${ }^{\mathrm{b}}$ University of Beira Interior, Department of Civil Engineering, 6200 Covilhã, Portugal \\ ${ }^{\mathrm{c}}$ University of Minho, Department of Civil Engineering, 4800 Guimarães, Portugal
}

Received 6 January 2007; received in revised form 23 March 2007; accepted 23 March 2007

Available online 9 May 2007

\begin{abstract}
This paper summarizes current knowledge about alkali-activated binders, by reviewing previously published work. As it is shown in Part 1, alkali-activated binders have emerged as an alternative to (ordinary Portland cement) OPC binders, which seem to have superior durability and environmental impact. The subjects of Part 2 of this paper are prime materials, alkaline activators, additives, curing type and constituents mixing order. Practical problems and theoretical questions are discussed. Topics for future work in this field are suggested.
\end{abstract}

(C) 2007 Elsevier Ltd. All rights reserved.

Keywords: Alkali-activated; Binders; Prime materials; Alkaline activator

\section{Contents}

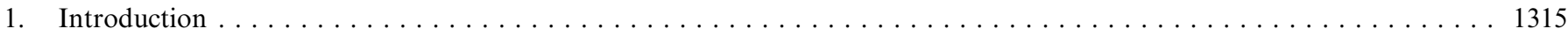

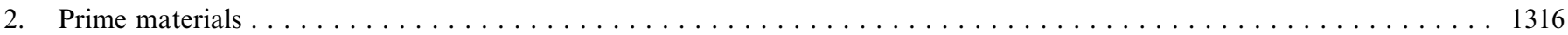

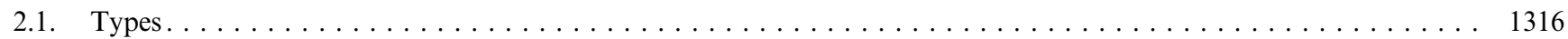

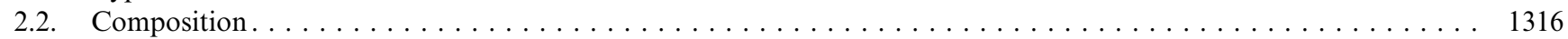

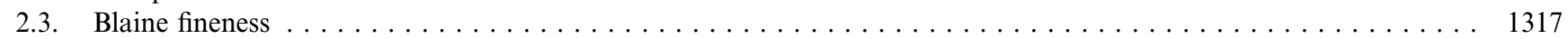

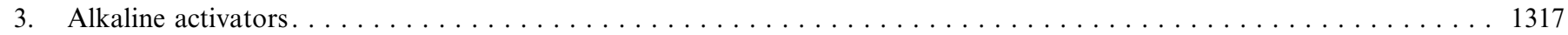

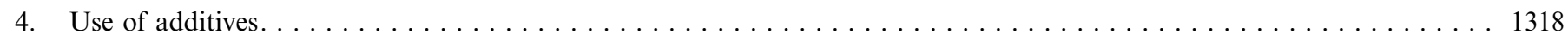

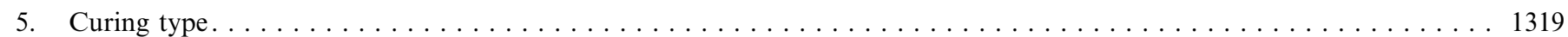

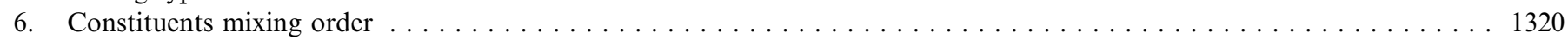

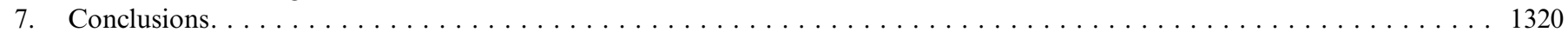

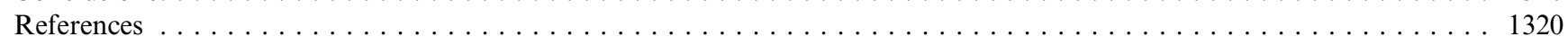

\footnotetext{
* Corresponding author. Tel.: +351272 339300; fax: +351 272339399.

E-mail addresses: fernandotorgal@est.ipcb.pt (F. Pacheco-Torgal), castro.gomes@ubi.pt (J. Castro-Gomes),said@civil.uminho.pt (S. Jalali).

${ }^{1}$ Tel.: +351 275 329990; fax: +351 275329969 .

2 Tel.: +351 253 510200; fax: +351253510213.
}

\section{Introduction}

As it is shown in Part 1 of the review, studies of alkaliactivated cements have a long history in the former Soviet 
Union, Scandinavia, and Eastern Europe, but they had an exponential increment after the research results of Joseph Davidovits which developed and patented binders obtained from the alkali-activation of metakaolin. According to that author, the new binder is generated by an adjustment of the process used by the Romans and the Egyptians. The alkaliactivation of alumino-silicate materials is a complex chemical process evolving dissolution of raw materials, transportation or orientation and polycondensation of the reaction products. Investigations about alkali-activated binders have deserved increased attention by the research community mainly due to its environmental performance and superior durability over ordinary Portland cement. It was just recently that Shi et al. [1] have published the first book about alkali-activated cements and concrete. The subjects of this paper are as follows.

\section{Prime materials}

\subsection{Types}

Theoretically, any material composed of silica and aluminium can be alkali- activated. So far the investigations performed have used the following prime materials:

(a) kaolinitic clays [2-6];

(b) metakaolin [7-10];

(c) fly ashes $[11,12]$;

(d) blast furnace slag [13-15];

(e) mixtures of fly ashes and slag [16,17];

(f) mixtures of fly ashes and metakaolin [18];

(g) mixtures of slag and metakaolin [19];

(h) mixtures of slag and red mud [20,21];

(i) mixtures of fly ashes and non-calcined materials like kaolin and stilbite [22].

For Palomo et al. [11], two models of alkali-activation could be established depending on the prime materials used. The first one is the case of the activation blast furnace slag $(\mathrm{Si}+\mathrm{Ca})$ with a mild alkaline solution, having $\mathrm{CSH}$ as the main reaction products. In the second model of alkaliactivation $(\mathrm{Si}+\mathrm{Al})$, the general example is the alkali-activation of metakaolin with medium to high alkaline solutions. The final product is characterized by a polymeric model and high mechanical strength. Although earlier Krivenko, quoted by Roy [23], had already separated the binding systems into two main categories: $\mathrm{Me}_{2} \mathrm{O}-\mathrm{MeO}-$ $\mathrm{Me}_{2} \mathrm{O}_{3}-\mathrm{SiO}_{2}-\mathrm{H}_{2} \mathrm{O}$ and $\mathrm{Me}_{2} \mathrm{O}-\mathrm{MeO}-\mathrm{SiO}_{2}-\mathrm{H}_{2} \mathrm{O}$. Xu and Deventer [24] studied the alkali-activation of 16 natural alumino-silicate minerals, having reported that all of them showed some reactivity. Stilbite activated with potassium hydroxide was the one displaying the highest mechanical strength. For Gourley [25], the use of metakaolin has the advantage of being white, although it needs several hour thermal treatment lowering its economic competitiveness. However, other authors [26-28] had already developed a flash calcinations technology, which allows to reduce the calcination time of kaolin to just a few minutes. Fernandez-Jimenez and Palomo [29] studied the reactivity of fly ashes to be alkali-activated, obtaining some reactivity for all of them. The most important reactivity parameters were reactive silica content, amorphous phase content, gradation and calcium content. This authors claim that iron and calcium do not influence mechanical strength because they are not found in the main reaction products. This claim is opposite to the results of Jaarsveld et al. [30], according to whom fly ashes when in presence of calcium lead to higher mechanical strength.

The thermal treatment of alumino-silicate materials causes changes in their structure with an increase in the amorphous phase. For that kind of structural change XRD analysis is not appropriate, so those changes are currently assessed by infrared emission spectra analysis (FTIR). According to some authors, the FTIR is accurate to detect small structural changes, being the most appropriate technique to assess structural changes of amorphous alumino-silicate materials [31]. Another good technique to detect structural changes is the nuclear magnetic resonance (NMR) spectroscopy. Therefore, the mechanical strength of alkali-activated binders depends on the structural conditions of the alumino-silicate materials, as natural materials lead to lower mechanical performance. Higher mechanical strength is associated to materials submitted to calcination such as fly ashes, blast furnace slag and metakaolin. As it happens in pozzolanic reactivity, alkali-activation reactivity depends on the amorphous content of silica and aluminium. The reactivity is linked to the material structure, being higher for higher amorphous content.

\subsection{Composition}

In order to achieve high strength and durability, Davidovits [7], based on the zeolite chemistry, recommended the use of certain molar ratios:

- for the alkaline activator: $\mathrm{SiO}_{2} / \mathrm{Na}_{2} \mathrm{O}=1.85$;

- for the metakaolin: $\mathrm{SiO}_{2} / \mathrm{Al}_{2} \mathrm{O}_{3}(3.5-4.5), \mathrm{Na}_{2} \mathrm{O} / \mathrm{SiO}_{2}$ (0.2-0.48), $\mathrm{Na}_{2} \mathrm{O} / \mathrm{Al}_{2} \mathrm{O}_{3}(0.8-1.6)$;

- between the activator and the metakaolin: $\mathrm{H}_{2} \mathrm{O} / \mathrm{Na}_{2} \mathrm{O}$ (10-25).

However, some authors argue that the parameters related to the prime material do not apply to other prime materials such as fly ashes and blast furnace slag, because not all the silica and aluminium are reactive $[4,32,33]$. In fact one must be aware that Davidovits used a high purity material that he named Kandoxi (Kaolin, Nacrite, Dickite, Oxide), obtained from the calcination of kaolin during $6 \mathrm{~h}$ at $750{ }^{\circ} \mathrm{C}$.

Some authors [6] have studied seven mixtures of metakaolin pastes activated with $\mathrm{NaOH}$ and waterglass, in order to study the molar ratios suggested by Davidovits [7]: 


$$
\begin{aligned}
& 0.2<\mathrm{Na}_{2} \mathrm{O} / \mathrm{SiO}_{2}<0.48 ; \quad 3.3<\mathrm{SiO}_{2} / \mathrm{Al}_{2} \mathrm{O}_{3}<4.5 ; \\
& 10<\mathrm{H}_{2} \mathrm{O} / \mathrm{Na}_{2} \mathrm{O}<25
\end{aligned}
$$

They have concluded that the optimum composition took place for $\mathrm{Na}_{2} \mathrm{O} / \mathrm{SiO}_{2}=0.25 ; \mathrm{H}_{2} \mathrm{O} / \mathrm{Na}_{2} \mathrm{O}=10$ and $\mathrm{SiO}_{2} /$ $\mathrm{Al}_{2} \mathrm{O}_{3}=3.3$. They also noticed that when using mixtures with a molar ratio $\mathrm{H}_{2} \mathrm{O} / \mathrm{Na}_{2} \mathrm{O}=25$ extremely low mechanical strength specimens were obtained, confirming the importance of the water content.

According to $\mathrm{Xu}$ and Deventer [24], the percentage of $\mathrm{CaO}$ and of $\mathrm{K}_{2} \mathrm{O}$, the ratio $\mathrm{Si} / \mathrm{Al}$ in the original mineral presents a correlation with mechanical strength. Fletcher et al. [34] studied sodium hydroxide alkali-activated metakaolin, in mixtures varying the $\mathrm{SiO}_{2} / \mathrm{Al}_{2} \mathrm{O}_{3}$ molar ratio. He concluded that mechanical strength is maximum for $\mathrm{SiO}_{2} / \mathrm{Al}_{2} \mathrm{O}_{3}=16$ molar ratio. However, for $\mathrm{SiO}_{2} /$ $\mathrm{Al}_{2} \mathrm{O}_{3}>24$, mechanical strength could not be determined because the hardened material behaves plastic-like, he also found that for high $\mathrm{SiO}_{2} / \mathrm{Al}_{2} \mathrm{O}_{3}>24$ a thermal treatment between 100 and $250{ }^{\circ} \mathrm{C}$ leads water to be expelled as bubbles leading to foam materials.

For binder execution, Davidovits [35] suggests the following average molar ratios to the composition of the hardened material:

$$
\begin{aligned}
& \text { Si:Al } 2.854 \text { (2.047-5.57); } \\
& \text { K:Al 0.556 (0.306-0.756); } \\
& \text { Si:K 6.13 (3.096-9.681); } \\
& \text { Ca:Al 0.286 (0.107-0.401); } \\
& \text { Si:Ca } 15.02 \text { (4.882-41.267). }
\end{aligned}
$$

Duxson et al. [36] also studied the activation of metakaolin with $\mathrm{NaOH}$ and waterglass concluding that the maximum strength was achieved for a $\mathrm{Si} / \mathrm{Al}=1.9$ molar ratio. Fernandez-Jimenez et al. [37] studied several types of fly ashes, having reported for the reactive phase a $\mathrm{Si} / \mathrm{Al}$ molar ratio between 1.42 and 2.38, although the molar ratio for the original fly ashes is lower, which means that $\mathrm{Al}$ has a less reactive phase than $\mathrm{Si}$. Therefore, what matters most is the $\mathrm{Si} / \mathrm{Al}$ molar ratio of the reactive phase, and not so much the $\mathrm{Si} / \mathrm{Al}$ molar ratio of the original prime material.

\subsection{Blaine fineness}

Some authors [38] found that mechanical strength of alkali-activated specimens does not increase very much when Blaine fineness of blast furnace slag increase from 5300 to $6700 \mathrm{~cm}^{2} / \mathrm{g}$. Talling and Brandstetr [39] obtained optimum strength for a slag Blaine fineness of $4000 \mathrm{~cm}^{2} /$ g. For Wang et al. [40] the optimum Blaine fineness depends on the type of slag and varies between 4000 and $5500 \mathrm{~cm}^{2} / \mathrm{g}$.

Granizo [41] studied alkali-activated metakaolin claiming that Blaine fineness is the most important parameter. Other authors [20] studied alkali-activated slag mortars obtaining lower mechanical strength when Blaine fineness increase from 4500 to $9000 \mathrm{~cm}^{2} / \mathrm{g}$. They also concluded that among several parameters Blaine fineness was the least relevant one. Those results are opposite to the ones noticed by Brough and Atkinson [42]. Those authors studied alkaliactivated slag mixtures, reporting that an increase in Blaine fineness from 3320 to $5500 \mathrm{~cm}^{2} / \mathrm{g}$ leads to an increase in mechanical strength from 65 to $100 \mathrm{MPa}$.

Other authors [43] reported that increasing metakaolin Blaine fineness from 15,670 to $25,550 \mathrm{~m}^{2} / \mathrm{kg}$ lead to an increase in mechanical strength from 55 to $74 \mathrm{MPa}$. According to them, that operation raises the available amount of aluminium to react with the alkaline activator. Therefore, more aluminium means that more $\left[\mathrm{Al}(\mathrm{OH})_{4}\right]^{-}$ tetrahedral groups able to attract negatively charge groups and therefore, increasing the reacted species amount. Generally speaking, blast furnace slag with higher Blaine fineness means more reactivity, but at the same time more hydration water, leading to higher porosity and lower strength. The results reflect different behaviour according to the two majors groups of materials susceptible of alkaline activation. Calcium free materials are more influenced by Blaine fineness increase.

\section{Alkaline activators}

The most used alkaline activators are a mixture of sodium or potassium hydroxide $(\mathrm{NaOH}, \mathrm{KOH})$ with sodium waterglass $\left(n \mathrm{SiO}_{2} \mathrm{Na}_{2} \mathrm{O}\right)$ or potassium waterglass $\left(n \mathrm{SiO}_{2} \mathrm{~K}_{2} \mathrm{O}\right)[6,7,11,15,18,22,42,44,45]$.

Katz [46] studied alkali-activated slags reporting an increase in mechanical strength when the concentration of the activator increases. Other authors have reported the same behaviour using alkali-activated metakaolin $[10,47]$. However, for the alkali-activation of fly ashes, Palomo et al. [11] reported that an activator with a $12 \mathrm{M}$ concentration leads to better results than a $18 \mathrm{M}$ concentration. Some authors used free waterglass alkaline activators, having noticed lower mechanical performances $[10,11]$. According to Palomo et al. [11], the alkaline activator plays a crucial role in the polymerization reaction, behaving more swiftly when the soluble silica is present. That statement is also shared by Criado et al. [48], according to whom waterglass favours the polymerization process leading to a reaction product with more $\mathrm{Si}$ and more mechanical strength.

Pinto [10] studied the alkali-activation of metakaolin reporting that the use of an alkaline activator with waterglass cause an increase in mechanical strength, from 30 to $60 \mathrm{MPa}$ in compression and from 5 to $7 \mathrm{MPa}$ in flexural strength. Fernandez-Jimenez and Palomo [12,29] reported an increase from 40 to $90 \mathrm{MPa}$ just after one day curing, when an alkaline activator with $\mathrm{NaOH}$ and waterglass are used instead of just $\mathrm{NaOH}$.

Wang et al. [40] states that the nature of the activator influence the mechanical strength of alkali-activated slag mortars, and that the optimum amount of $\mathrm{Na}_{2} \mathrm{O}$ varies from $3 \%$ to $5.55 \%$ of slag mass. Those authors reported that using an alkaline activator with a silica modulus of 
1-1.5 leads to higher mechanical strengths. They also noticed that using powder waterglass leads to lower performance when compared to the liquid form.

Jaarsveld et al. $[32,49]$ claim that the $\mathrm{H}_{2} \mathrm{O} / \mathrm{SiO}_{2}$ molar ratio is very important in the study of alkali-activated mixtures. However, this statement is not confirmed by others [50], who claim it does not influence mechanical strength. Kirschener and Harmuth [51] studied the activation of metakaolin with $\mathrm{NaOH}$ and waterglass having noticed that mechanical strength increases when $\mathrm{Na}_{2} \mathrm{O} / \mathrm{SiO}_{2}$ molar ratio decreases.

Other authors [52] also studied the alkali-activation of metakaolin, noticing that the mechanical strength was higher for a molar ratio $\mathrm{Si} / \mathrm{Al} / \mathrm{Na}$ of $2.5: 1: 1.3$. According to Fernandez-Jimenez et al. [15], the most relevant parameters that influence mechanical strength of alkali-activated blast furnace slag mortars are: the nature of the alkaline activator, the concentration of the activator, curing temperature, and the least one was Blaine fineness. Those authors also noticed that the optimum concentration of the alkaline activator varies between $3 \%$ and $5 \%$ of $\mathrm{Na}_{2} \mathrm{O}$ of slag mass. Using a $\mathrm{Na}_{2} \mathrm{O}$ amount above those limits, causes cost inefficient mixtures and with efflorescence problems. Other authors [53] also claim that the activation of blast furnace slag with a waterglass based activator $\left(\mathrm{M}_{\mathrm{s}}=1.25\right)$ leads to the highest mechanical strength. However, those authors achieved the optimum strength using $8 \%$ of $\mathrm{Na}_{2} \mathrm{O}$. Xu and Deventer [24] confirm that the use of waterglass increase the dissolution of the prime materials. They studied the alkali-activation of different natural alumino-silicate minerals, having noticed that most of them could not provide enough $\mathrm{Si}$ to start the geopolymerization, thus needing additional soluble sílica. Puertas et al. [16] studied pastes of fly ashes/slag and claim that compressive strength is influenced by the concentration of sodium hydroxide. They also reported compressive strength increase with slag content increase, explaining that with higher reactivity of the blast furnace slag. Other authors used a mixture of stilbite and kaolin noticing that $\mathrm{SiO}_{2} /$ $\mathrm{M}_{2} \mathrm{O}$ molar ratio influences the polymerization degree. They also confirm that increasing sodium content leads to increasing dissolution of silica and aluminium [54]. Lee and Deventer [55] reported on increasing dissolution due to an excess of alkali, but it also leads to a formation of a alumino-silicate gel in the first curing ages, leading to mechanical strength decrease. Some authors noticed that the waterglass/sodium hydroxide molar ratio influences compressive strength $[10,45]$, as the use of molar ratio of 2.5 leads to an expressive strength increase of alkali-activated fly ash [45]. Krizan and Zivanovic [56] studied the alkali-activation of blast furnace slag with waterglass and metasilicate noticing that the highest strength was obtained for $M_{\mathrm{s}}(1.2-1.5)$. Other authors [57] used fly ash based mixtures activated with waterglass and sodium hydroxide. They reported that when the $\mathrm{NaOH}$ amount increase lowering the silica modulus $\left(M_{\mathrm{s}}=1.64\right)$, the silicate excess crystallized and was responsible for higher strength.
Pinto [10] studied the alkali-activation of metakaolin mortars with $\mathrm{NaOH}$ and waterglass. He used an activator/binder $(\mathrm{A} / \mathrm{B})$ mass ratio between 1 and 0.75 reporting that below 0.85 the mortar could hardly be mixed. This observation is opposite to the results of other authors $[11,18,24]$ who have been able to used $(\mathrm{A} / \mathrm{B})$ ratios of 0.25 and 0.30. Fernandez-Jimenez and Palomo [12] studied the activation of fly ash, with several activators in which the $\mathrm{Na}_{2} \mathrm{O}$ content changes from $5 \%$ to $15 \%$. They concluded that the $\mathrm{SiO}_{2} / \mathrm{Na}_{2} \mathrm{O}$ molar ratio as well as the W/B ratio influence mechanical strength. They noticed that using a $\mathrm{Na}_{2} \mathrm{O}$ content of $5.5 \%$ by fly ash mass leads to a very low $\mathrm{pH}$, affecting the reaction development in a negative way and also that the $\mathrm{Na}_{2} \mathrm{O}$ content increase leads mechanical strength increase, and that the use of $14 \%$ of $\mathrm{Na}_{2} \mathrm{O}$ by fly ash mass leads to optimum mechanical performance. Again, different alkali concentrations are used for different prime materials, and that calcium free materials use higher alkali concentrations.

\section{Use of additives}

Although Davidovits investigations used alumino-silicate materials calcium free. The fact is that Pyrament cement is composed by $80 \%$ of portland cement (allegedly due to its low cost) and also by $20 \%$ of geopolymeric materials activated by potassium carbonate having citric acid as a retarder [58]. Also the patented geopolymeric cements PZ-Geopoly ${ }^{\circledR}$ and Geopolycem ${ }^{\circledR}$ have $11 \%$ of $\mathrm{CaO}$ in their composition [59] confirming the importance of calcium in alkali-activated binders.

Douglas et al. [60] noticed that the replacement of blast furnace slag by silica fume and fly ash in alkali-activated mixtures led to mechanical strength increase. However, the strength diminishes considerably when high replacement amounts are used. Cheng et al. [61] studied alkali-activated slag, having reported a considerable increase in mechanical strength when $1.9-3.4 \%$ of $\mathrm{Ca}(\mathrm{OH})_{2}$ was used. Other authors [8] studied alkali-activated metakaolin/calcium hydroxide based mixtures reporting that an increase of the amount of metakaolin over calcium hydroxide causes an increase of the formation of alkaline alumino-silicate compounds due to increasing dissolved alumino-silicate species and also that temperature increase hasted the reaction, lowering ion mobility. In another investigation, those authors [9] studied the influence of the sodium hydroxide concentration on the nature of the formed reaction products, concluding that parameter has a crucial role on them:

- When the alkaline activator concentration is $10 \mathrm{M}$ or higher, dissolution of $\mathrm{Ca}(\mathrm{OH})_{2}$ is very difficult due to the presence of hydroxides $\left(\mathrm{OH}^{-}\right)$, meaning there will not be enough to the formation of CSH gel. Instead sodium based alumino-silicate is formed. When that occurs, it attracts $\mathrm{OH}^{-}$to its structure, lowering the amount of them and allowing the formation of $\mathrm{CSH}$ gel as a secondary reaction product. 
- When the alkaline activator concentration is lower than $5 \mathrm{M}$, the amount of hydroxides $\left(\mathrm{OH}^{-}\right)$is very low, so the dissolution of calcium hydroxide takes place, meaning enough $\mathrm{Ca}^{2+}$ will be present to form CSH gel. Besides, low alkaline concentration media prevents the metakaolin dissolution, so there is not enough dissolved aluminium to the formation of alkaline alumino-silicates, meaning that silica will be free to form $\mathrm{CSH}$.

Lee and Deventer [31] studied the influence of inorganic salt in alkali-activated mixtures of fly ash and kaolin, having reported that strength and durability are negatively affected by chloride salts, because they formed crystals inside the structure lowering its strength. They also found that carbonate salts are beneficial because they diminish the amount of dissolved water preventing the hydrolytic attack. Other authors [62] reported that calcium increased strength due to the formation of $\mathrm{Ca}-\mathrm{Al}-\mathrm{Si}$ amorphous structures. They found the coexistence of geopolymeric gel and CSH (Fig. 1) and suggested that the formation of those two phases would explain the durability of ancient binders.

Escalante-Garcia et al. [63] studied alkali-activated slag mortars with $10 \%$ replacement by geothermal waste silica. They noticed that when the activator is made only of $\mathrm{NaOH}$, the replacement always causes strength increase. However, when the activator uses waterglass, the strength increase happens only before seven days curing. After that time the replacement leads to lower strength due to an excess of silica, originating the formation of $\mathrm{H}_{2} \mathrm{SiO}_{3}$. Pinto [10] studied alkali-activated metakaolin, reporting mechanical strength increase when using a $12 \mathrm{M}$ concentration sodium hydroxide activator and calcium hydroxide percentage from $0 \%$ to $20 \%$. However, for a concentration of $15 \mathrm{M}$ he noticed that the calcium hydroxide percentage did not influence strength.

\section{Curing type}

Different curing conditions, having reported for different prime materials, activated with different activators. Fernandez-Jimenez et al. [15] studied alkali-activated blast furnace slag, noticing that curing temperature causes strength decrease when the activator is made of $\mathrm{NaOH}$ plus waterglass. However, when waterglass is not present, a strength increase happens. Other authors [53] reported that when curing temperature is used it leads to a strength increase in alkali-activated slag for the initial curing times but with a decrease for older times. That can be explained by the increase in slag solubility as well as speed hydration increase, as already reported by Glukhovsky et al. [64]. However, others believe that strength decrease may be related to the formation of hydrated material around the slag grains preventing the development of hydration [65]. That explanation had already been claimed by Camarim [66]. According to Silva [67], the rise in curing temperature leads also to the increase in the amount of unreacted material. Other authors [68] also noticed a strength decrease for long curing time with temperature. That suggests that some water may remains in the hardened binder, keeping the "gelular" character of geopolymers. Collins and Sanjayan $[69,70]$ studied the activation of slag with powder waterglass, having reported lower strength for air curing without any kind of isolation ( $\mathrm{fc}^{90}=33 \mathrm{MPa}$ ) when compared to air curing with isolation $\left(\mathrm{fc}^{90}=50 \mathrm{MPa}\right)$ or water curing $\left(\mathrm{fc}^{90}=55 \mathrm{MPa}\right)$. Jaarsveld et al. [71] reported that for alkali-activated metakaolin/fly ash mixtures, certain curing temperature leads to strength increase. However, for long

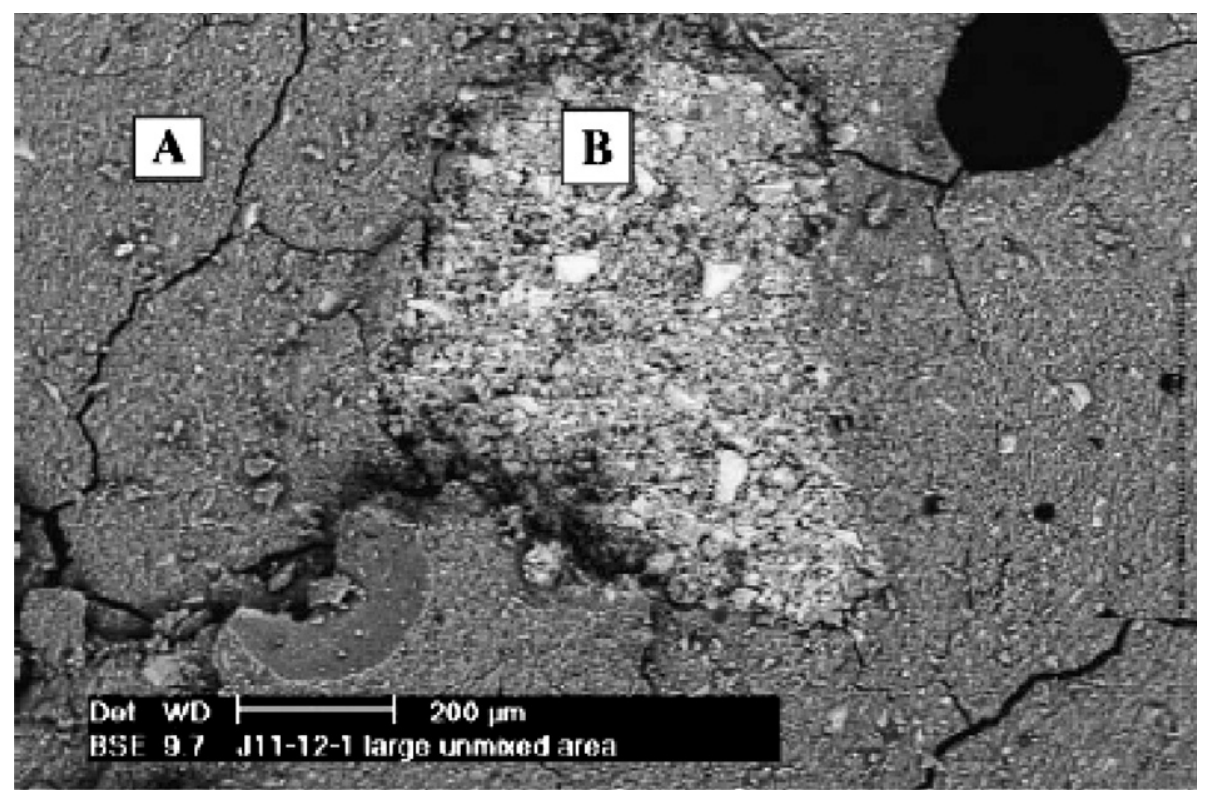

Fig. 1. Formation of geopolymeric gel (A) and CSH gel (B) [61]. 
curing time it weakens the material structure due to excessive shrinkage. Other authors [10] also claim the need of the isolation of the hardened specimens in order to prevent water evaporation. Brough and Atkinson [42] studied the alkali-activation of slag with waterglass, noticing that the use of a curing for $12 \mathrm{~h}$ at $80^{\circ} \mathrm{C}$ allows a strength increase from 7 to $72 \mathrm{MPa}$ when compared to a $20^{\circ} \mathrm{C}$ curing. Wang et al. [40] also used alkali-activated slag, reporting that curing temperature depends on the activator nature, being almost irrelevant when high concentration activators are used. Kirschener and Harmuth [51] obtained the highest strength using alkali-activated metakaolin cured at $75^{\circ} \mathrm{C}$ during $4 \mathrm{~h}$. They also confirm that water curing leads to a strength decrease. Criado [48] studied the alkali-activation of fly ashes suggesting the isolation of the specimens because for certain curing conditions a carbonation process would arise, lowering the $\mathrm{pH}$ and the mechanical strength Bakharev [72] believes curing temperature is a crucial aspect about the alkali-activation of fly ashes because of the thermal activated barrier, that must be over passed so that the reaction may start. That statement is confirmed by the investigations of Katz [46] who noticed an impressive strength increase with curing temperature. Since the activation energy is higher for fly ash than it is for blast furnace slag, the curing temperature is less important for the former case. This statement is confirmed by the studies of other authors $[15,16,73]$. So one may conclude that if during the curing process, evaporation water loss occurs, it causes strength decrease. Also that after curing temperature exposure, waterglass or $\mathrm{NaOH}$ based specimens must be isolated to prevent strength decrease.

\section{Constituents mixing order}

Some authors believe that the optimum mixing order for alkali-activated binders as follows: First the solids are mixed. Separately, the activator is prepared and put to rest and finally the activator is mixed with the solids $[18,19,74]$. Pinto et al. [75] studied the alkali-activation of metakaolin confirming that this mixing order leads to the best results. Cheng and Chiu [19] reported the best mixing is as follows: mix metakaolin and potassium hydroxide for $10 \mathrm{~min}$, then add waterglass and slag and mix for $5 \mathrm{~min}$, place the mixtures in $50 \times 50 \times 50 \mathrm{~mm}^{3}$ molds and vibrate them for more $5 \mathrm{~min}$. Therefore, is important to confirm if the mixing order remains the same for other prime materials and also how it is influenced by the type of alkaline activator.

\section{Conclusions}

So far, investigations about alkali-activated binders allow to conclude that apart from reactive prime materials such as metakaolin, or industrial by-products such as fly ashes and slag, also other several alumino-silicate minerals could be submitted to alkali-activation. However, it must be noticed that those studies used highly pure mineral samples and it is not expected that less pure or even waste minerals has the same reactivity. That way, future research about the activation of alkali-activation of alumino-silicate mineral wastes is needed.

The current knowledge about alkaline activators shows that the most appropriate are made of hydroxides and soluble silica. Despite that, the influence of sodium hydroxide concentration and the ratio waterglass/hydroxide ratio are not quite fully understood because it is not expected that when different prime materials were used, that the optimum alkaline concentration and the optimum silica modulus remain the same.

The use calcium hydroxide showed that it leads to an increase in mechanical strength. However, it is still not clear why that is so. Also which is the optimum amount of that additive and how could that behaviour be influenced by different prime material? Besides as calcium hydroxide dissolution depends on alkaline concentration that parameter must be analysed together with activator composition. Also there is a lack of knowledge about the role played by the iron oxides in alkali-activated mixtures, although it is known to contribute to strength development of OPC binders. That issue is very relevant because most of the mineral wastes fit to be used as prime materials are iron rich.

\section{References}

[1] Shi C, Roy D, Krivenko P. Alkali-activated cements and concrete. London: Taylor \& Francis Ltd.; 2006.

[2] Davidovits J. Synthesis of new high temperature geo-polymers for reinforced plastics/composites. SPE PACTEC 79 Society of Plastic Engineers, Brookfield Center; 1979. p. 151-4.

[3] Davidovits J, Sawyer JL. Early high strength mineral polymer. US Patent 4.509.958; 1985.

[4] Rahier H, Van Melle B, Biesemans M, Wastiels J, Wu X. Low temperature synthesized aluminosilicate glasses. Part I. Low temperature reaction stoichiometry and structure of a model compound. J Mater Sci 1996;31:71-9.

[5] Rahier H, Simons W, Van Melle B, Biesemans M. Low temperature synthesized aluminosilicate glasses. Part III. Influence of composition of the silica solution on production, structure and properties. J Mater Sci 1997;32:2237-47.

[6] Barbosa VF, MacKenzie KJ, Thaumaturgo C. Synthesis and characterisation of materials based on inorganic polymers of alumina and sílica: sodium polysialate polymers. Int J Inorg Polym 2000;2:309-17.

[7] Davidovits J. Chemistry of geopolymeric systems. Terminology. In: Proceedings of 99 geopolymer conference, vol. 1. 1999. p. 9-40.

[8] Alonso S, Palomo A. Calorimetric study of alkaline activation of calcium hydroxide-metakaolin solid mixtures. Cem Concr Res 2001;31:25-30.

[9] Alonso S, Palomo A. Alkaline Activation of metakaolin and calcium hydroxide mixtures: influence of temperature, activator concentration and solids ratio. Mater Letts 2001;47:55-62.

[10] Pinto AT. Alkali-activated metakaolin based binders. PhD Thesis. University of Minho; 2004 [only in Portuguese].

[11] Palomo A, Grutzek MW, Blanco MT. Alkali-activated fly ashes. A cement for the future. Cem Concr Res 1999;29:1323-9.

[12] Fernandez-Jimenez A, Palomo J. Composition and microstructure of alkali activated fly ash binder: effect of the activator. Cem Concr Res 2005;35:1984-92.

[13] Purdon AO. The action of alkalis on blast furnace slag. J Soc Chem Ind 1940;59:191-202. 
[14] Wang S-D, Scrivener K. Hydration products of alkali activated slag cement. Cem Concr Res 1995;25:561-71.

[15] Fernandez-Jimenez A, Palomo J, Puertas F. Alkali activated slag mortars. Mechanical strength behaviour. Cem Concr Res 1999;29: 1313-21.

[16] Puertas F, Martinez-Ramirez S, Alonso S, Vasquez T. Alkaliactivated fly ash/slag cement. Strength behaviour and hydration products. Cem Concr Res 2000;30:1625-32.

[17] Puertas F, Fernandez-Jimenez A. Mineralogical and microstructural characterisation of alkali-activated fly ash/slag pastes. Cem Concr Compos 2003;25:287-92.

[18] Swanepoel JC, Strydom CA. Utilization of fly ash in a geopolymeric material. Appl Geochem 2002;17:1143-8.

[19] Cheng TW, Chiu JP. Fire resistant geopolymer produced by granulated blast furnace slag. Miner Eng 2003;16:205-10.

[20] Pan Zhihua, Li Dongxu, Yu Jian, Yang Nanry. Hydration products of alkali-activated slag red mud cementitious material. Cem Concr Res 2002;32:357-62.

[21] Pan Zhihua, Li Dongxu, Yu Jian, Yang Nanry. Properties and microstructure of the hardened alkali-activated red mud-slag cementitious material. Cem Concr Res 2003;33:1437-41.

[22] Xu H, Deventer JSJ, Jannie SJ. Geopolymerisation of multiple minerals. Min Eng 2002;15:1131-9.

[23] Roy DM. Alkali-activated cements. Opportunities and challenges. Cem Concr Res 1999;29:249-54.

[24] Xu H, Deventer JSJ. The geopolymerisation of alumino-silicate minerals. Int J Miner Process 2000;59:247-66.

[25] Gourley JT. Geopolymers: Opportunities for environmentally friendly construction materials. In: Materials 2003 conference. Australasia: Institute of Materials Engineering.

[26] Salvador S, Davies TW. Modelling of combined heating and dehydroxylation of kaolinite particles of fly ash calcinations: production of metakaolin. Process Adv Mater 1994;9:128-35.

[27] Salvador S. Pozzolanic properties of flash-calcined kaolinite. A comparative study with soak-calcinated products. Cem Concr Res 1995;25:102-12.

[28] Salvador S. A semi-mobile flash dryer/calciner unit manufacture pozzolana from raw clay soils - application to soil stabilization. Constr Build Mater 2000;14:109-17.

[29] Fernandez-Jimenez A, Palomo A. Characterisation of fly ashes Potential reactivity as alkaline cements. Fuel 2003;82: 2259-65.

[30] Jaarsveld JGS, Deventer JSJ, Lukey GC. The characterisation of source materials in fly ash-based geopolymers. Mater Letts 2003:1272-80.

[31] Lee WKW, Deventer JSJ. The effects of inorganic salt contamination on the strength and durability of geopolymers. Colloids Surf 2002;211:115-26.

[32] Jaarsveld JGS, Deventer JSJ, Lorenzen L. The potential use of geopolymeric materials to immobilise toxic metals: Part I. Theory and applications. Miner Eng 1997;10:659-69.

[33] Hos JP, McCormick PG, Byrne LT. Investigation of a synthetic aluminosilicate inorganic polymer. J Mater Sci 2002;37: 2311-6.

[34] Fletcher RA, Mackenzie KJD, Nicholson CL, Shimada S. The composition range of alumino silicate geopolymers. J Eur Ceram Soc 2005;25:1471-7.

[35] Davidovits J. Geopolymer chemistry and sustainable development. The poly(sialate) terminology: a very useful and simple model for the promotion and understanding of green-chemistry. In: Proceedings of 2005 geopolymer conference, vol. 1. 2005. p. 9-15.

[36] Duxon P, Provis J, Grant L, Mallicoat S, Kriven W, Deventer J. Understanding the relationship between geopolymer composition, microstructure and mechanical properties. Colloids Surf 2005;269: $47-58$.

[37] Fernandez-Jimenez A, Palomo J, Sobrados I, Sanz J. The role played by reactive alumina content in the alkaline activation of fly ashes. Micropor Mesopor Mater 2006;91:111-9.
[38] Andersson R, Gram H. Properties of alkali-activated slag. In: Alkaliactivated slag. Stockholm: Swedish Cement and Concrete Research Institute; 1988 [9-63CBI Research].

[39] Talling B, Brandstetr J. Present state and future of alkali-activated slag concretes. In: 3rd International conference on fly ash, silica fume, slag and natural pozzolans in concrete. Trondheim Norway; 1989. p. $1519-46$.

[40] Wang S-D, Scrivener K, Pratt P. Factors affecting the strength of alkali-activated slag. Cem Concr Res 1994;24:1033-43.

[41] Granizo ML. Activation alcalina de metacaolin: desarrolllo de nuevos materials cementantes. PhD Thesis. University Autonoma of Madrid; 1998 [only in Spanish].

[42] Brough AR, Atkinson A. Sodium silicate-based alkali-activated slag mortars. Part I. Strength, hydration and microstructure. Cem Concr Res 2002;32:865-79.

[43] Weng L, Sagoe-Crentsil K, Brown T, Song S. Effects of aluminates on the formation of geopolymers. Mater Sci Eng 2005;117:163-8.

[44] Escalante-Garcia JI, Mendez-Nodell J, Gorokhovsky AV, FraireLuna PE, Mancha-Molinar H, Mendoza-Suarez G. Reactivity and mechanical properties of alkali activated blast furnace slag. Bol Soc Espan Ceram Vidrio 2002;41:451-8.

[45] Hardjito D, Wallah SE, Sumajouw, Rangan BV. Properties of geopolymer concrete with fly ash source material: effect of mixture composition. In: Seventh CANMET/ACI international conference on recent advances in concrete technology, Las Vegas, USA; 2002.

[46] Katz A. Microscopic study of alkali-activation fly ash. Cem Concr Res 1998;28:197-208.

[47] Wang Hongling, Li Haihong, Yan Fengyuan. Synthesis and mechanical properties of metakaolinite-based geopolymer. Colloids Surf 2005;268:1-6.

[48] Criado M, Palomo A, Fernandez-Jimenez A. Alkali activation of fly ashes. Part 1: Effect of curing conditions on the carbonation of the reaction products. Fuel 2005;84:2048-54.

[49] Jaarsveld JGS, Deventer J. The effect of the alkali metal activator on the properties of fly-ash based geopolymers. Ind Eng Res 1999;38:3932-41.

[50] Hardjito D, Wallah SE, Rangan BV. Study on engineering properties of fly ash based geopolymer concrete. J Austr Ceram Soc 2002;38:44-7.

[51] Kirschner Andrea, Harmuth Harald. Investigation of geopolymer binders with respect to their application for building materials. Ceram Silic 2004;48:117-20.

[52] Rowles M, O'Connor B. Chemical optimisation of the compressive strength of aluminosilicate geopolymers synthetised by sodium silicate activation of metakaolinite. J Mater Chem 2003;13:1161-5.

[53] Bakharev T, Sanjayan J, Cheny Y-B. Alkali-activation of Australian slag cements. Cem Concr Res 1999;29:113-20.

[54] Xu H, Deventer JSJ. Effect of alkali metals on the preferential geopolymerization of stilbite/kaolinite mixtures. Ind Eng Chem Res 2001;40:3749-56.

[55] Lee WKW, Deventer JSJ. The effect of ionic contaminants on the early-age properties of alkali-activated fly ash-based cements. Cem Concr Res 2002;32:577-84.

[56] Krizan Darko, Zivanovic Branislav. Effects of dosage and modulus of water glass on early hydration of alkali-slag cements. Cem Concr Res 2002;32:1181-8.

[57] Xie Zhaohu, Xi Yunping. Hardening mechanisms of an alkalineactivated class F fly ash. Cem Concr Res 2001;31:1245-9.

[58] Davidovits J. Properties of geopolymers cements. In: Proceedings of the first international conference on alkaline cements and concretes. Kiev, Ukraine: Scientific Research Institute on Binders and Materials; 1994. p. 131-49.

[59] Davidovits J. Geopolymers: Man-made rock geosynthesis and the resulting development of very early high strength cement. J Mater Edu 1994;16:91-139.

[60] Douglas E, Bilodeau A, Brandstetr J, Malhotra VM. Alkali activated ground granulated blast furnace slag concrete: preliminary investigations. Cem Concr Res 1991;21:101-8. 
[61] Cheng QH, Tagnit-Hamou A, Sarkar SL. Strength and microstructural properties of waterglass activated slag. Mater Res Soc Symp Proc 1992;245:49-54.

[62] Yip CK, Deventer SJS. Microanalysis of calcium silicate hydrate gel formed within a geopolymeric binder. J Mater Sci 2003;38: 3851-60.

[63] Escalante-Garcia JI, Gorokhovsky AV, Mendonza G, Fuentes AF. Effect of geothermal waste on strength and microstructure of alkaliactivated slag cement mortars. Cem Concr Res 2003;33:1567-74.

[64] Glukhovsky VD, Zaitsev Y, Pakhomov V. Slag-alkaline cements and concrete structure, properties, technological and economical aspects of use. Silic Ind 1983;10:197-200.

[65] Silva MG, Agopyan V. Hydration of blast furnace slag cements. Influence of temperature. Technical magazine BT/PCC/204. University of São Paulo; 1998 [only in Portuguese].

[66] Camarim G. Thermal curing performance of blast furnace slag and portland cement mixtures. PhD Thesis. University of São Paulo; 1995 [only in Portuguese].

[67] Silva MG. Thermal curing of pastes and mortars using blast furnace slag. PhD Thesis. University of São Paulo; 1998 [only in Portuguese].
[68] Khalil M, Merz E. Immobilisation of intermediate-level waste in geopolymers. J Nucl Mater 1994;2:141-8.

[69] Collins F, Sanjayan J. Strength and shrinkage properties of alkaliactivated slag concrete placed into a large column. Cem Concr Res 1999;29:659-66.

[70] Collins F, Sanjayan J. Microcracking and strength development of alkali-activated slag concrete. Cem Concr Res 2001;23:345-52.

[71] Jaarsveld JGS, Deventer JSJ, Lukey GC. The effect of composition and temperature on the properties of fly ash and kaolinite based geopolymers. Chem Eng J 2002;89:63-73.

[72] Bakharev AT. Geopolymeric materials prepared using class F fly ash and elevated temperature curing. Cem Concr Res 2005;35:1224-32.

[73] Fernandez-Jimenez A, Puertas F. Alkali activated slag cements: kinetic studies. Cem Concr Res 1997;27:359-68.

[74] Jaarsveld JGS, Deventer JSJ, Lorenzen L. Factors affecting the immobilisation of metals in geopolymerised fly ash. Metall Mater Trans B 1998;29:283-91.

[75] Pinto A, Fernandes P, Said J. Geopolymer manufacture and applications - main problems when using concrete technology. In: Proceedings of 2002 geopolymer conference, Melbourne, Australia. 